\title{
In-vitro Immunomodulatory activity of Azadirachta indica A.Juss. Ethanol: water mixture against HIV associated chronic $\mathrm{CD}^{+}{ }^{+}$T-cell activation/ exhaustion
}

Omalla A. Olwenyi ${ }^{1,2,3^{*}}$ (D) Bannet Asingura ${ }^{1,4}$, Prossy Naluyima', Godwin Upoki Anywar ${ }^{5}$, Justine Nalunga ${ }^{1}$, Mariam Nakabuye ${ }^{1}$, Michael Semwogerere ${ }^{1}$, Bernard Bagaya ${ }^{4}$, Fatim Cham ${ }^{1}$, Allan Tindikahwa ${ }^{1}$, Francis Kiweewa ${ }^{1}$, Eliezer Z. Lichter ${ }^{6}$, Anthony T. Podany ${ }^{7}$, Courtney V. Fletcher ${ }^{7}$, Siddappa N. Byrareddy ${ }^{3}$ and Hannah Kibuuka ${ }^{1}$

\begin{abstract}
Background: In Sub-Saharan Africa, herbal therapy continues to be utilized for HIV-1 disease management. However, the therapeutic benefits of these substances remain ambiguous. To date, little is known about the effects of these plant extracts on chronic CD4 + T-cell activation and exhaustion which is partly driven by HIV-1 associated microbial translocation.

Methods: Effects of Azadirachta indica, Momordica foetida and Moringa oleifera ethanol: water mixtures on cell viability were evaluated using the Guava PCA system. Then, an in-vitro cell culture model was developed to mimic CD4+ T cell exposures to antigens following HIV-1 microbial translocation. In this, peripheral blood mononuclear cells (PBMCs) isolated from HIV negative $(n=13)$, viral load $<1000$ copies per $\mathrm{mL}(n=10)$ and viral load $>1000$ copies per $\mathrm{mL}(n=6)$ study participants from rural Uganda were treated with Staphylococcus enterotoxin B (SEB). Then, the candidate plant extract ( $A$. indica) was added to test the potential to inhibit corresponding CD4+ $T$ cell activation. Following BD Facs Canto II event acquisition, variations in \%CD38, \%CD69, Human Leukocyte Antigen -DR (HLA-DR), Programmed cell death protein 1 (PD-1), T-cell immunoglobulin and mucin domain-containing protein 3 (Tim-3), interferon gamma (IFN $\gamma$ ) and interleukin 2 (IL-2) CD4 + T cell expression were evaluated.

Results: Following exposure to SEB, only $A$. indica demonstrated a concentration-dependent ability to downregulate the levels of CD4 + T cell activation. At the final concentration of $0.500 \mu \mathrm{g} / \mathrm{mL}$ of $A$. indica, a significant downregulation of CD4 + CD38 + HLA-DR+ expression was observed in HIV negative $(p<0.0001)$ and both HIV infected groups $(P=0.0313)$. This plant extract also significantly lowered SEB induced \% CD4+ T cell HLAD R, PD-1 and Tim-3 levels. PD-1 and CD69 markers were only significantly downmodulated in only the HIV negative $((p=0.0001$ and $p=0.0078$ respectively) and viral load $<1000$ copies per $\mathrm{ml}(p=0.0078)$ groups.

(Continued on next page)
\end{abstract}

\footnotetext{
*Correspondence: omalla.olwenyi@unmc.edu; aomalla@muwrp.org

${ }^{1}$ Makerere University, Walter Reed Project, P.O Box 16524, Kampala, Uganda

2Department of Pathology and Microbiology, University of Nebraska Medical Center, Omaha, NE, USA

Full list of author information is available at the end of the article
}

C C The Author(s). 2021 Open Access This article is licensed under a Creative Commons Attribution 4.0 International License, which permits use, sharing, adaptation, distribution and reproduction in any medium or format, as long as you give appropriate credit to the original author(s) and the source, provide a link to the Creative Commons licence, and indicate if changes were made. The images or other third party material in this article are included in the article's Creative Commons licence, unless indicated otherwise in a credit line to the material. If material is not included in the article's Creative Commons licence and your intended use is not permitted by statutory regulation or exceeds the permitted use, you will need to obtain permission directly from the copyright holder. To view a copy of this licence, visit http://creativecommons.org/licenses/by/4.0/. The Creative Commons Public Domain Dedication waiver (http://creativecommons.org/publicdomain/zero/1.0/) applies to the data made available in this article, unless otherwise stated in a credit line to the data. 
(Continued from previous page)

Conclusion: A. indica exhibited the in-vitro immunomodulatory potential to inhibit the continuum of SEB induced CD4+ T-cell activation/ exhaustion without impacting general T-cell specific functions such as cytokine secretion. Additional studies are needed to confirm A. indica as a source of natural products for targeting persistent immune activation and inflammation during ART.

Keywords: Immunomodulation, $\mathrm{CD}^{+} \mathrm{T}$ cell activation/exhaustion, Azadirachta indica (A. indica) ethanol: water mixture, Staphylococcal enterotoxin B (SEB), Microbial translocation

\section{Background}

Life prolonging antiretroviral therapy (ART) has remarkably improved the quality of life of people living with HIV (PLWH) worldwide. However, in resource-limited settings such as sub-Saharan Africa (SSA), incapacitated health care systems limit access to ART [1-3]. In these settings, cultural differences and poor health care force PLWH resort to herbal therapy for alternative/ complementary treatment [4-7]. Hence, it is common for PLWH who are actively enrolled on ART to concurrently use traditional herbal medicines [8]. This warrants the need for studies investigating any immune-boosting benefits arising from the routine use of medicinal plants for HIV diseases management.

HIV principally infects CD $4^{+} \mathrm{T}$ cells and skews diverse cellular pathways to favour its replication [9]. This is also accompanied by persistent $\mathrm{CD}^{+} \mathrm{T}$ cell activation as denoted by increased surface expression of (1) the early activation marker CD69, (2) the antigen presenting molecule Human Leukocyte Antigen - DR (HLA-DR), (3) the metabolite marker CD38 [10, 11]. This state of chronic immune activation is majorly driven by continuous responses to bacterial antigens arising from gut microbial translocation [12].

Early in infection, HIV causes irreparable damage to the gut epithelium. This causes gut microbes and bacterial products to transverse the gut protective barrier [13]. This sets the stage for the establishment of systemic immune activation and subsequent HIV pathogenesis. As such, chronic $\mathrm{T}$ cell activation has been linked to accelerated progression to AIDS and is suggested as an even better predictor of AIDS events compared to viral load and $\mathrm{CD}^{+}{ }^{+} \mathrm{T}$ cell count in HIV infected individuals [14]. In addition, the continuous response of $\mathrm{CD}^{+} \mathrm{T}$ cells towards various antigenic stimuli during the course of HIV infection leads to increased $\mathrm{CD}^{+}{ }^{+} \mathrm{T}$ cell exhaustion. This is exemplified by the elevated surface expression of program cell death protein 1 (PD-1) and Tim 3 checkpoint inhibitory receptors [15]. In summary, the increased expression of multiple exhaustion markers on $\mathrm{CD}_{4}^{+} \mathrm{T}$ cells is associated with the loss of HIV-specific cell function. This is characterized by a reduction in Interleukin 2 (IL-2) and Tumour Necrosis Factor alpha (TNF $\alpha$ ) cytokine secretion $[16,17]$.
Blockade of exhaustion markers like anti PD-1 has previously been shown to improve disease outcomes by limiting hyper immune activation and promoting $\mathrm{CD}_{4}^{+}$ $\mathrm{T}$ cell function. This later facilitates improved immunological control of the virus [18-20]. Succinctly, Mylvaganam $\mathrm{GH}$ et al, suggest that the administration of therapeutics designed to limit $\mathrm{T}$ cell activation / exhaustion could provide additional benefits when combined with ART [19]. In SSA, HIV-1 infected individuals have higher levels of $\mathrm{T}$ cell activation compared to persons from developed countries. This is mainly due to the high burden of endemic pathogens that continuously activate the immune system [21-23]. This further emphasizes the need for urgent therapy-based modalities focused on dampening hyper-immune activation within these communities.

As recently as 2019, Bourke et al. showed that longterm use of the antibiotic Cotrimoxazole together with ART lowers monocyte secretion of pro-inflammatory cytokines. However, Cotrimoxazole did not reduce the levels of immune activation in $\mathrm{CD}^{+} \mathrm{T}$ cells following in-vitro stimulation with the bacterial bi-product Staphylococcal Enterotoxin B (SEB) [23].

To advance the search for compounds targeting HIV-1 associated $\mathrm{CD}^{+}{ }^{+} \mathrm{T}$-cell activation, we tested ethanolic plant extracts for their potential immune-modulatory potential. Based on a library of medicinal plants reportedly used by PLWH in SSA, the following plant species were selected: Momordica foetida Schumach, Azadirachta indicia A. Juss. and Moringa oleifera [7, 24, 25].

Here, we report that following in-vitro stimulation of HIV infected peripheral blood mononuclear cells (PBMCs) with SEB, $A$. indica leaf ethanol: water mixture is capable of down-regulating $\mathrm{CD} 4+\mathrm{T}$-cell activation and exhaustion. This suggests that $A$. indica could serve as a potential source of bioactive compounds that could be developed for targeting chronic immune activation in PLWH.

\section{Methods}

Preparation of plant extracts

Plant collection and preparation

For the collection of plant specimens, permission was sought from Uganda National Council for Science and 
Technology (UNCST). Later on, guidance was obtained from the Department of Plant Sciences, Microbiology \& Biotechnology at Makerere University. Fresh M. foetida (leaves), A. indica (leaves) and $M$. oleifera (leaves) were harvested from Mabira Central Forest Reserve in Uganda. The plant specimens were identified by a botanist (Godwin Anywar, Department of Plant Sciences, Microbiology and Biotechnology Makerere University) using field guides [26, 27]. Voucher specimens of the selected species were collected following standard procedures described in Martin et al 1995 [28] and deposited at the Makerere University herbarium for confirmation. All plant materials were processed following the World Health Organisation (WHO) guidelines on Good Agricultural and Collection Practices (GACP) for medicinal plants (WHO, 2003) [29].

\section{Plant extraction}

The harvested plant parts were then washed separately with distilled water to remove debris, oven-dried at $40^{\circ} \mathrm{C}$ for 5 days and ground to a fine powder using a blender. Whilst processing the plant species, the blender was thoroughly cleaned using $70 \%$ ethanol. Solid-liquid extraction was performed by soaking $200 \mathrm{~g}$ of fine powder from each plant specimen in $400 \mathrm{~mL}$ of $70 \%$ ethanol for $24 \mathrm{~h}$. The resultant crude extracts were separately filtered through Whatman Grade 1 qualitative filter paper (Sigma-Aldrich, USA) and precipitated using a rotary evaporator (Buchi ${ }^{\circ}$ rotary evaporator Model, R-205) at reduced pressure. Then the precipitates were dried overnight in a desiccator. The final yields of the dried crude ethanol-water mixtures ranged from 20 to $25 \%$. Following this, $0.98 \mathrm{~g}$ of $A$. indicia, $0.24 \mathrm{~g}$ of $M$. foetida, and $1.07 \mathrm{~g}$ of $M$. oleifera dissolved in $1 \mathrm{ml}$ of dimethyl sulfoxide (DMSO) (Sigma-Aldrich, USA) to make respective stock solutions. The stock solutions were later filtered through $0.22 \mu \mathrm{m}$ Millex-GP syringe filters (Merck, Darmstadt Germany). The final plant ethanol-water mixtures were stored at $4{ }^{\circ} \mathrm{C}$ and later reconstituted for further experimentation.

\section{Study participants and consent information}

All study procedures were approved by the Makerere University College of Health Sciences School of Public Health Higher Degrees, Research and Ethics Committee (HDREC), UNCST. For in-vitro screening of the immunomodulatory effects of the selected plant extracts, HIV1 infected individuals on ART and healthy HIV negative individuals residing in Kayunga district, in central Uganda were targeted for enrolment. Study participants were eligible for enrolment if they: (1) provided written informed consent. (2) were aged between 18 and 49 years. (3) had 6-month medical data including at least a complete blood count (CBC) profile, either viral load
(VL) result and/ or CD4 count (if HIV infected). (4) had normal blood haemoglobin count. (5) had not reported herbal medicine use within 7 days of blood sample collection. A questionnaire was administered to capture: the frequency of herbal medicine use, commonly used herbal plants, method of herbal extract preparation and whether several plant varieties were used concurrently (Supplementary document).

\section{HIV screening and viral load testing}

In all study participants, HIV-1 infection screening was performed sequentially using Determine ${ }^{\mathrm{Tm}} \mathrm{HIV}-1 / 2$ AG/ $\mathrm{AB}$ COMBO (Abbott Laboratories, Illinois, USA), Chembio HIV 1/2 STAT-PAK ${ }^{\bullet}$ Assay (Chembio Diagnostics, New York, USA) and Uni-Gold Recombigen ${ }^{\circ}$ HIV-1/2 (Trinity Biotech, Wicklow, Ireland) following respective manufacturers' instructions [30-32]. Thereafter, in HIV positive study participants, HIV-1 viral load (VL) was determined using the COBAS ${ }^{\circ}$ AmpliPrep/ COBAS $^{\bullet}$ TaqMan $^{\circ}$ HIV-1 Test, v2.0 (Roche Holding AG, Basel, Switzerland) [33].

\section{Blood sample collection and PBMC processing}

Sterile whole blood samples were collected from consenting study participants in $8.5 \mathrm{ml}$ BD vacutainer acid citrate dextrose (ACD) tubes [34] and PBMCs were isolated within $8 \mathrm{~h}$ of sample collection using the FicollHypaque density centrifugation technique as previously described [35]. PBMC counts and viability were determined by Muse ${ }^{\circ}$ Count \& Viability Assay kit (Merck, Darmstadt Germany), a Guava Personal Cell Analysis (PCA) system, and Guava Viacount CytoSoft ${ }^{\text {tw }}$ Software Version 6.2.2 (Guava Technologies, USA) following manufacturer's instructions [36]. PBMCs with cell viability greater than $85 \%$ were cryopreserved at $1 \times 10^{7}$ cells/ $\mathrm{mL}$ in freeze media containing 10\% DMSO, $10 \%$ heat inactivated fetal bovine serum (FBS), $1 \%$ penicillinstreptomycin (pen-strep), 2\% HEPES buffer, 2\% Lglutamine and 75\% RPMI-1640. All reagents used in the freeze media were obtained from St. Louis, MO SigmaAldrich, USA.

\section{Cytotoxicity screening based on cell viability testing}

To evaluate the cytotoxicity of the plant extracts, cryopreserved PBMCs from HIV negative blood packs were thawed and rested overnight in 10\% complete media (10\% FBS, $1 \%$ pen-strep, 2\% HEPES buffer, 2\% Lglutamine and $85 \%$ RPMI-1640) at $37^{\circ} \mathrm{C}, 5 \% \mathrm{CO}_{2}$ and $90 \%$ relative humidity (RH). All reagents in $10 \%$ complete media were obtained from St. Louis, MO Sigma-Aldrich, USA. Then PBMC counts and viability assessments were performed as previously described [36, 37 and PBMCs with greater than $85 \%$ cell viability were seeded in polystyrene 96 -well plates $\left(1 \times 10^{5}\right.$ cells/well $)$ 
containing $200 \mu \mathrm{L}$ of $10 \%$ complete media per well with varying concentrations (serial dilutions) of either SEB (St. Louis, MO Sigma-Aldrich, USA) or cyclosporine A (St. Louis, MO Sigma-Aldrich, USA) or the plant extracts. The PBMCs were then incubated at $37^{\circ} \mathrm{C}, 5 \% \mathrm{CO}_{2}$ and $90 \% \mathrm{RH}$ for $36 \mathrm{~h}$ with regular replenishment (12-h intervals) of the culture media. Finally, PBMC counts and viability assessments were performed as previously described [36, 37] to determine the maximum concentration of each plant extract at which the lowest level of cell death is observed. Only the maximum concentration of each ethanol-water mixture at which PBMC viability was maintained above $80 \%$ was considered for further study.

\section{Evaluating the effect of plant ethanol-water mixtures on $\mathrm{CD}^{+} \mathrm{T}$-cell activation and exhaustion following SEB stimulation \\ In-vitro cell culture and stimulation}

Following SEB stimulation, cryopreserved PBMCs from HIV negative blood packs $(n=5)$ were seeded in a polystyrene 96 -well plate $\left(1 \mathrm{X} 10^{6}\right.$ cells/well) containing $200 \mu \mathrm{L}$ of $10 \%$ complete media per well with different treatment conditions. These included: $1 \mu \mathrm{g} / \mathrm{mL}$ SEB (positive control); $0.015 \mu \mathrm{g} / \mathrm{mL}$ of cyclosporine A (negative control) [38]; $1 \mu \mathrm{g} / \mathrm{mL}$ SEB and $0.015 \mu \mathrm{g} / \mathrm{mL}$ cyclosporin A (Cyclo + SEB); $0.5 \mu \mathrm{g} / \mathrm{mL} \mathrm{A.} \mathrm{indica} \mathrm{and} 1 \mu \mathrm{g} /$ $\mathrm{mL}$ SEB (A. indica $+\mathrm{SEB})$. In addition, $0.5 \mu \mathrm{g} / \mathrm{mL} M$. oleifera and $1 \mu \mathrm{g} / \mathrm{mL}$ SEB (M. oleifera + SEB), $0.5 \mu \mathrm{g} / \mathrm{ml}$ $M$. foetida and $1 \mu \mathrm{g} / \mathrm{mL}$ SEB (M. foetida + SEB); and finally, $0.5 \mu \mathrm{g} / \mathrm{mL}$ of $A$. indica only were also included. An unstimulated condition was also included as a negative control and incubation performed at $37^{\circ} \mathrm{C}, 5 \% \mathrm{CO}_{2}$ and $90 \% \mathrm{RH}$ for $24 \mathrm{~h}$.

\section{Flow cytometry surface staining}

The treated PBMCs were then washed twice in phosphate buffer saline (PBS) and stained with BD Multitest ${ }^{\text {tx }}$ CD4 (clone SK3) FITC/CD38 (clone HB7) PE/CD3 (clone SK7) PerCP/Anti-HLA-DR (clone L243) APC (BD Biosciences, San Jose, CA), Tim-3 BV421 (Clone 7D3, BD Biosciences, San Jose CA), PD-1 PE-Cy7 (Clone EH12.1, BD Biosciences, San Jose CA), CD69 APC-H7 (Clone FN50, BD Biosciences, San Jose, CA) and LIVE/ DEAD $^{\mathrm{m}}$ Fixable Aqua Stain (Invitrogen, Carlsbad, CA). The PBMCs were then fixed with $2 \%$ paraformaldehyde (PFA), washed again in PBS and events acquired using a BD FACS Canto II. Fluorescence minus one (FMO) controls were used to set cut-off gates for markers that did not have a clear resolution during data analysis (Supplementary Figure 1).
Testing the potential of the a.indica ethanol-water mixture to downregulate CD4+ $T$ cell activation/ exhaustion in HIV infected individuals

After observing that only the A. indica ethanol-water mixture reduced SEB-induced $\mathrm{CD}_{4}{ }^{+} \mathrm{T}$ cell activation, HIV negative PBMCs $\left(1 \mathrm{X} 10^{6}\right.$ cells/well) were treated with increasing concentrations of $A$. indica extracts $(0.0$ to $0.5 \mu \mathrm{g} / \mathrm{mL}$ ) and $1 \mu \mathrm{g} / \mathrm{mL}$ of SEB in $10 \%$ complete media for 24 -h at $37{ }^{\circ} \mathrm{C}, 5 \% \mathrm{CO}_{2}$ and $90 \% \mathrm{RH}$. Later experiments were then performed with a focused intent of testing the ability of $A$. indica to reduce the levels of chronic $\mathrm{CD}^{+}{ }^{+} \mathrm{T}$ cell activation/ exhaustion in HIV negative $(n=13)$, viral load less than 1000 copies per $\mathrm{ml}(n=$ $10)$ and viral load greater than 1000 copies per $\mathrm{ml}(n=$ 6) study groups.

\section{Evaluating the effect of $A$. indica extract on gag-specific $C D 4^{+} T$-cell cytokine responses}

After observing that the A. indica extract downmodulated SEB-induced $\mathrm{CD}^{+}{ }^{+} \mathrm{T}$ cell activation and exhaustion, next we sought to determine whether this was accompanied by altered HIV specific $\mathrm{CD}^{+}{ }^{+} \mathrm{T}$ cell IL2 and INF- $\gamma$ responses. Cryopreserved PBMCs were thawed and rested overnight at $37^{\circ} \mathrm{C}, 5 \% \mathrm{CO}_{2}$ and $90 \%$ $\mathrm{RH}$. Then the PBMCs were seeded in a polystyrene 96well plate $\left(1 \times 10^{6}\right.$ cells/well) containing $200 \mu \mathrm{L}$ of $10 \%$ complete media per well with either of the following treatment conditions: $2.5 \mu \mathrm{g} / \mathrm{mL}$ of Gag i.e. PepMix HIV GAG (Ultra, JPT peptides Inc., Berlin, Germany) [39], $0.5 \mu \mathrm{g} / \mathrm{mL}$ A. indica and $2.5 \mu \mathrm{g} / \mathrm{mL}$ Gag (A. indica + Gag), $2.5 \mu \mathrm{g} / \mathrm{mL}$ Gag and $2 \mu \mathrm{g} / \mathrm{mL}$ SEB (positive control). Afterwards, $1 \mu \mathrm{g} / \mathrm{mL}$ of anti-CD28 (Clone CD28.2, BD Biosciences, San Jose CA) and $1 \mu \mathrm{g} / \mathrm{mL}$ of anti-CD49 (Clone L25, BD Biosciences, San Jose CA) were added as co-stimulants, then $2 \mu \mathrm{g} / \mathrm{mL}$ brefeldin A (BD Biosciences, San Jose CA) and $1 \mu \mathrm{M}$ monensin (BD Biosciences, San Jose CA) were added to block cytokine efflux from the Golgi apparatus. The 96-well plates were then incubated at $37{ }^{\circ} \mathrm{C}, 5 \% \mathrm{CO}_{2}$ and $90 \%$ relative humidity (RH) for $10 \mathrm{~h}$. After, the PBMCs were stained with LIVE/DEAD ${ }^{\text {ma }}$ Fixable Aqua Stain (Invitrogen, Carlsbad $\mathrm{CA})$, washed in PBS and then Fc receptor blocked using Human BD Fc Block ${ }^{\mathrm{Tw}}$ (BD Biosciences, San Jose, CA). Cell surface staining was then performed using CD4 PE Cy7 (Clone SK3 BD Biosciences, San Jose, CA), CD8 PE Cy5 (Clone RPA-T8 BD Biosciences, San Jose, CA) and CD3 APC-H7 (Clone SK7, BD Biosciences, San Jose, CA). Following this, the PBMCs were fixed using $2 \%$ PFA and permeabilized with BD permeabilization buffer prior to intracellular staining with IL-2 BV421 (Clone MQ1-17H12, BD Biosciences, San Jose, CA) and interferon gamma (IFN- $\gamma$ ) APC (Clone B27, BD Pharmin$\operatorname{gen}^{\mathrm{Tw}}$, San Jose, CA). Finally, events were acquired within $24 \mathrm{~h}$ using a BD FACSCanto ${ }^{\mathrm{mm}}$ II. Corresponding Flow 
Cytometry Standard (FCS) data files were evaluated following the gating strategies in Supplementary Figures 1 and 2.

\section{Statistical analysis}

FCS files were analysed using FlowJo Version 10.0.7 [40] and all statistical analyses were performed using GraphPad Prism version 7.0 software [41]. Within each group, paired data analyses were calculated using the Wilcoxon matched-pairs signed rank test for differences within medians. Results with $p$-values $<0.05$ were considered statistically significant.

\section{Results}

\section{Study participant characteristics}

Between June and August 2017, 29 study participants aged between 18 and 49 years were enrolled in the study. All participants had normal complete blood counts (CBC) /blood haemoglobin counts. Their median weight was $62(50.0-81.3) \mathrm{kgs}$. Of the enrolled participants, 15 $(52 \%)$ were female while $14(48 \%)$ were male. Notably, $45 \%$ of the study participants recruited were HIV-1 positive. Of the 16 HIV-1 infected subjects, 9 were females and 7 were males. Within the HIV-1 infected participants, 9 had VL less than 1000 copies/mL and were considered virally 'suppressed' according to recommended guidelines for VL monitoring in resource-limited settings $[42,43]$. Lastly, of all the recruited study participants, 9 (31\%) reported herbal use. Amongst these herbal users, 7 were female while 2 were male. Our self-reporting questionnaire revealed that 4 of the 9 herbal users prepared the herbal concoctions themselves (self-preparation), (Table 1).

\section{Effect of plant extracts on PBMC viability}

The cytotoxicity experiments were conducted for $24 \mathrm{~h}$ to test the ability of the extracts to maintain plasma membrane integrity and minimize cell death. Also, an $80 \%$ cell viability threshold was selected based on previous drug screening studies which showed that drug concentrations which maintain cell viabilities greater than $80 \%$ in culture usually possess acceptable toxicity profiles [44, 45].

After $24 \mathrm{~h}$ of PBMC culture, a general concentrationdependent trend was observed whereby increasing concentrations of plant extracts was accompanied by a simultaneous decline in PBMC viability (Fig. 1). The $A$. indica extract exhibited a cytotoxicity profile that was characterized by fluctuating PBMC viability at concentrations below $0.5 \mu \mathrm{g} / \mathrm{mL}$ that was maintained above the cut-off of $80 \%$ viability. Above $0.5 \mu \mathrm{g} / \mathrm{mL}$, there was a steady decline in viability (Fig. 1a). Conversely for the $M$. oleifera extract, above $0.5 \mu \mathrm{g} / \mathrm{mL}$, a progressive loss in cell viability that dropped below the $80 \%$ threshold was
Table 1 Demographics of Study Participants

\begin{tabular}{|c|c|}
\hline \multicolumn{2}{|l|}{ Age } \\
\hline Study participants & 29 \\
\hline Over 18 years & 29 \\
\hline \multicolumn{2}{|l|}{ Immune Status } \\
\hline Normal complete blood count (Hemoglobin > $12 \mathrm{~g} / \mathrm{dl}$ ) & 29 \\
\hline Weight > $50 \mathrm{Kg}$ & 29 \\
\hline Weight, Kg (range) & $\begin{array}{l}62(50- \\
81.3)\end{array}$ \\
\hline \multicolumn{2}{|l|}{ Sex } \\
\hline Male (\%) & $14(48)$ \\
\hline Female (\%) & $15(52)$ \\
\hline \multicolumn{2}{|l|}{ HIV Infection Status } \\
\hline Negative & 13 \\
\hline Positive (VL < 1000 copies/ml) & 9 \\
\hline Negative (VL > 1000 copies/ml) & 7 \\
\hline \multicolumn{2}{|l|}{ Documented Herbal Medicine Users } \\
\hline Vernonia amygdalina & 4 \\
\hline Momordica foetida & 3 \\
\hline Bidens pilosa & 1 \\
\hline Hoslundia opposita & 1 \\
\hline \multicolumn{2}{|l|}{ Frequency of Herbal Medicine Use } \\
\hline History of herbal use & 9 \\
\hline At least once per year & 7 \\
\hline Monthly herbal medicine & 1 \\
\hline $\begin{array}{l}\text { Prepared the herbal extracts themselves (self- } \\
\text { preparation) }\end{array}$ & 4 \\
\hline Used a combination of at least 2 plants & 4 \\
\hline Tobacco smokers & 1 \\
\hline Alcohol consumers & 4 \\
\hline
\end{tabular}

From: In-Vitro Screening of Selected Tropical African Plants reveals the Potential Immunomodulatory Activity of Azadirachta indica Ethanolic Extract against HIV Associated Chronic CD4 ${ }^{+}$T-Cell Activation/ Exhaustion

noticed (Fig. 1b). In turn, for the M. foetida extract, PBMC viability fluctuated between a range of 70 to $90 \%$ at concentrations between 0.0 to $0.5 \mu \mathrm{g} / \mathrm{mL}$. This was followed by a steady decline in viability, (less than $80 \%$ ), at concentrations above $0.5 \mu \mathrm{g} / \mathrm{mL}$ (Fig. 1c). Viability was maintained following prolonged cellular exposures to $A$. indica that lasted up to $48 \mathrm{~h}$.

Effect of plant extracts on $\mathrm{CD}^{+}{ }^{+}$T-cell activation following in-vitro stimulation with SEB

A. indica, M. foetida and M. oleifera extracts were further evaluated to determine their effect on $\mathrm{CD}_{4}^{+} \mathrm{T}$ cell activation (\%CD4 + CD38 + HLA-DR+) following stimulation with SEB. Preliminary assessment using PBMCs from five HIV-1 negative individuals showed that only the $A$. indica extract reduced SEB-induced $\mathrm{CD}^{+}{ }^{+}$T-cell activation since the \%CD $4+\mathrm{CD} 38+$ HLA-DR+ cells 


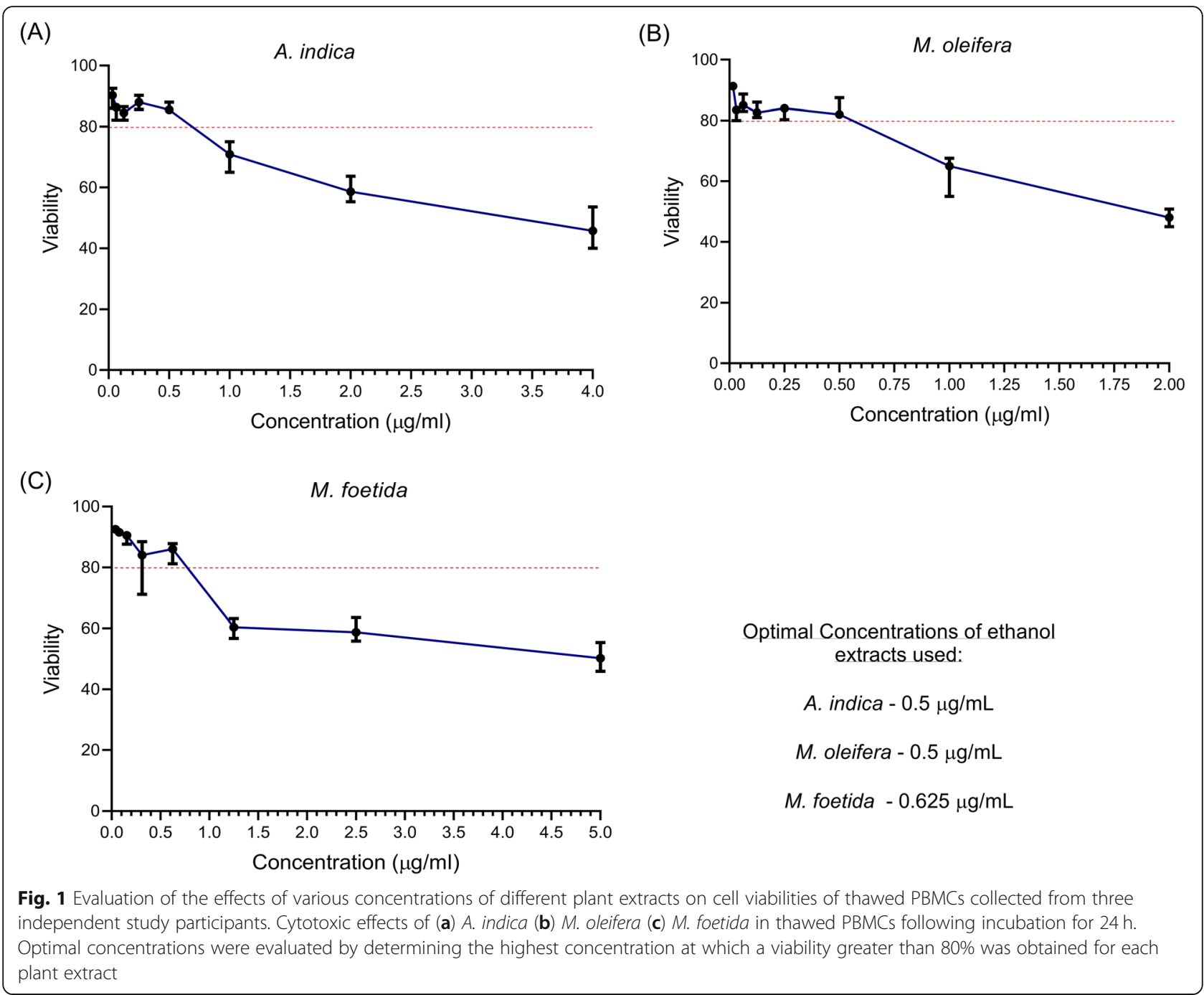

reduced from $1.470(0.400-2.870) \%$ in the positive control to $0.640(0.079-1.210) \%$ in the A. indica + SEB treatment condition, $(p=0.027)$ (Fig. $2 \mathrm{~b})$. In addition, the observed downregulation of $\mathrm{CD} 4^{+} \mathrm{T}$ cell activation was concentration-dependent at a range of 0.0 to $0.5 \mu \mathrm{g} /$ $\mathrm{mL}$ since increasing concentrations of the $A$. indica extract decreased the level of SEB-induced co-expression of CD38 and HLA-DR on CD4 ${ }^{+} \mathrm{T}$ cells (Fig. 2c).

Based on the above results, $A$. indica was selected as opposed to the other plant extracts tested in this study. This was because that it was the only candidate extract that significantly downregulated CD38+/HLA-DR+ coexpression in SEB stimulated CD4+ $\mathrm{T}$ cells in a concentration-dependent manner. Thus, $A$. indica was tested on PBMCs from study participants with known HIV-1 status, $\mathrm{CBC}$ and haemoglobin count. In HIV negative study participants, $0.5 \mu \mathrm{g} / \mathrm{mL}$ of $A$. indica reduced SEB-induced CD4 ${ }^{+} \mathrm{T}$ cell activation from 3.355 $(2.380-7.130) \%$ in the positive control to $2.030(0.79-$
4.420) $\% \mathrm{CD} 4+\mathrm{CD} 38+$ HLA-DR + cells $(p=0.0001)$ in the $A$. indica + SEB treatment condition. In parallel comparative experiments, the immunomodulatory effects of $A$. indica extract mirrored the known inhibitory properties of cyclosporin A which also reduced SEBinduced $\mathrm{CD}^{+}{ }^{+} \mathrm{T}$ cell activation from 3.355 (2.380-7.130) $\%$ to $1.860(0.9300-4.660) \%$ CD $4+$ CD $38+$ HLA-DR+ cells $(p=0.0006)$ (Fig. $2 \mathrm{~d})$. In separate conditions where the PBMCs obtained from HIV-1 negative individuals were not exposed to SEB, distinct changes in \% CD4 + CD38 + HLA-DR + cells were seen. Notably, the $0.5 \mu \mathrm{g} /$ $\mathrm{mL} A$. indica alone condition had similar \%CD $4+$ CD38 + HLA-DR+ frequencies as the unstimulated condition. However, the $0.5 \mu \mathrm{g} / \mathrm{mL} \mathrm{A}$. indica alone $(1.595$ $(0.500-3.640)) \%$ and the unstimulated condition 1.770 $(0.760-3.660) \%$ possessed lower levels of \% CD4+ CD38 + HLA-DR+ cells than the $0.015 \mu \mathrm{g} / \mathrm{mL}$ of cyclosporine A alone/ negative control condition (2.635 (1.690-4.540) \%), ( $p=0.0085$ and $p=0.0038$ respectively) 


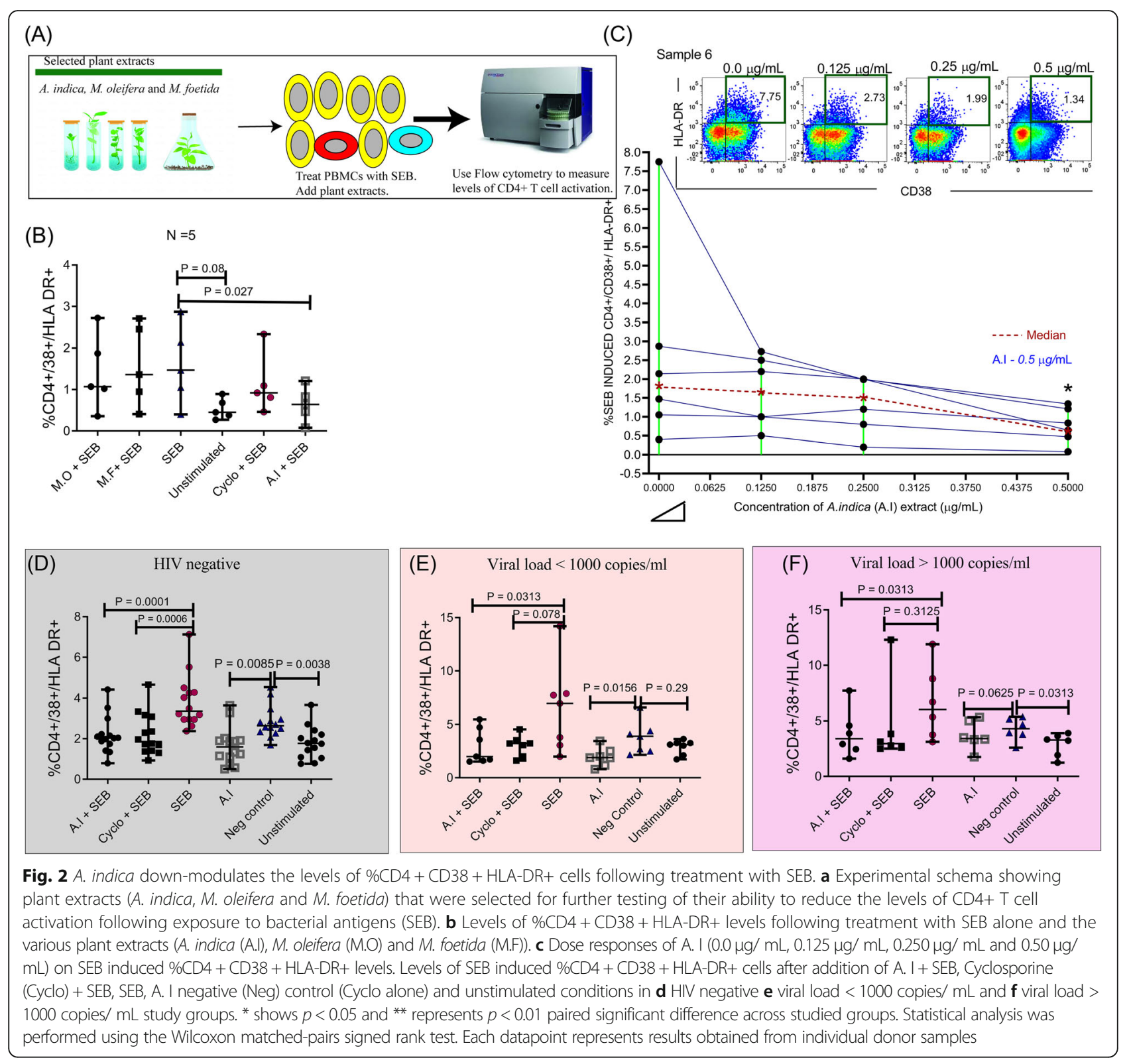

(Fig. 2d). Similar inhibitory effects were observed in HIV-1 infected participants. The $A$. indica extract reduced SEBinduced $\mathrm{CD} 4^{+} \mathrm{T}$ cell activation in PBMCs by greater than 1.5 folds from participants with or without suppressed viremia, ( $p=0.0313$ in both cases) (Fig. 2e and f). Likewise, as observed in the HIV-1 negative participants, the $A$. indica alone condition had close to two-fold lower levels of $\%$ CD $4+$ CD38 + HLA-DR+ cells in comparison to cyclosporine A alone conditions in PBMCs from participants with suppressed viremia $(p=0.0156)$ (Fig. 2e).

\section{Effect of the $A$. indica ethanol-water mixture on early $\mathrm{CD}^{+} \mathrm{T}$ cell activation and subsequent exhaustion} Having noticed that A.indica down modulated levels of CD4 + CD38 + HLA-DR+ co-expression, we sought to test whether this plant extract would have effects on different stages of CD4+ T cell activation. The A. indica extract reduced the expression of the early $\mathrm{T}$-cell activation marker CD69 and PD-1/ Tim-3 exhaustion markers in a similar fashion as cyclosporine A. In HIV negative study participants, $A$. indica extract reduced SEB-induced CD69 expression from 11.95 (9.00-22.80) $\%$ in the positive control to $8.12(3.35-13.10) \%$ in the $A$. indica + SEB treatment condition $(p=0.0006)$. In parallel, the observed $A$. indica extract mediated reduction of SEB-induced CD69 expression was equivalent to the anticipated inhibitory effect of cyclosporine A $(p=0.0006)$ (Fig. 3a). A similar trend was observed in participants with suppressed viremia where both the $A$. indica extract and cyclosporine A reduced SEB-induced CD69 


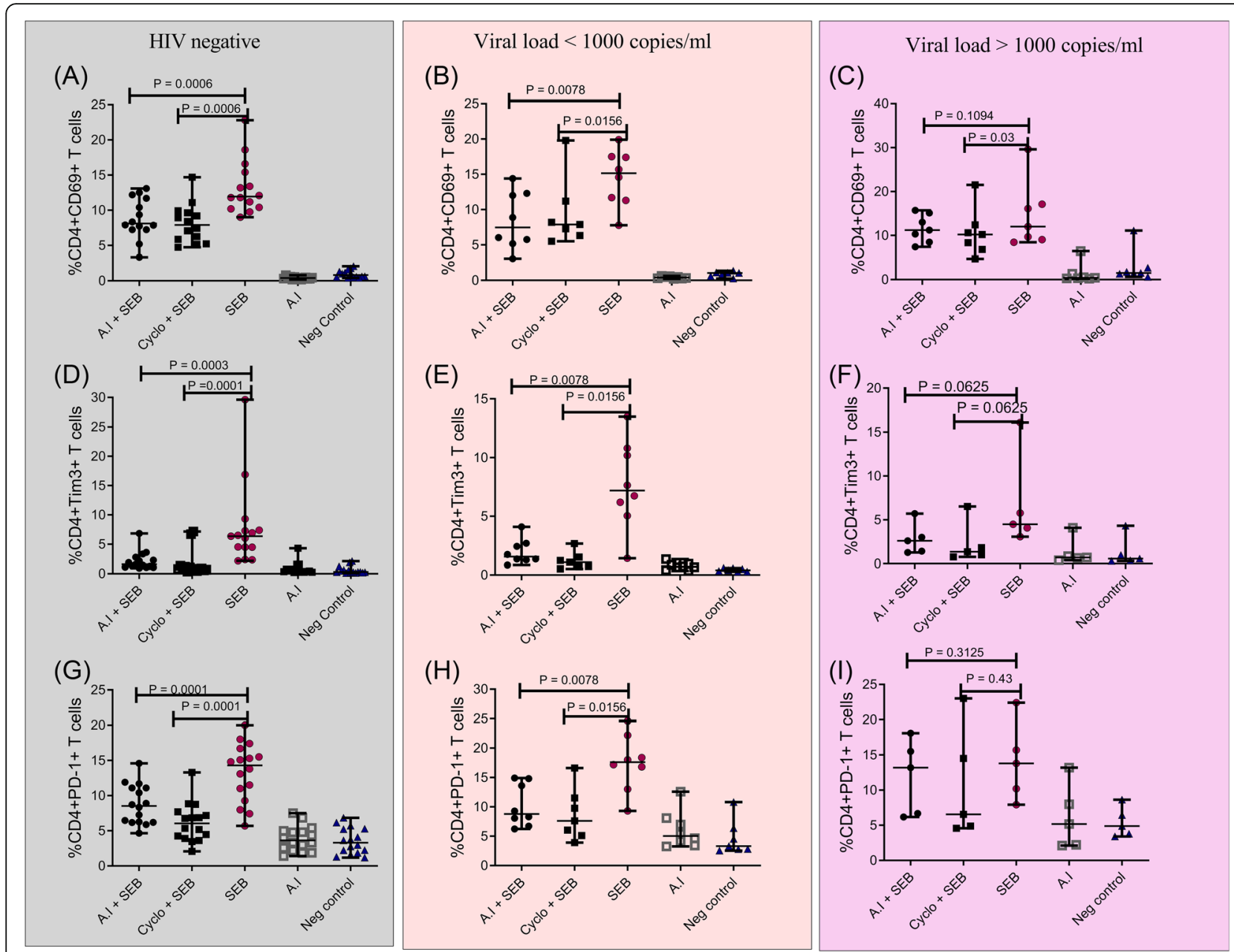

Fig. 3 A. indica also reduces the levels of other markers of SEB induced immune activation (CD69) and exhaustion (PD-1 and Tim-3) in PBMCS obtained from study participants. Levels of SEB induced \%CD4+/CD69+ T cells after addition of A. indica (A.I) + SEB, Cyclosporine (Cyclo) + SEB, SEB, A. I negative (Neg) control (Cyclo alone) and unstimulated conditions in (a) HIV negative (b) viral load $<1000$ copies/ $\mathrm{mL}$ and (c) viral load $>$ 1000 copies/ mL study groups. \%CD4+/Tim3+ T cell levels following the maintenance of similar stimulatory conditions as in (a-c) that involved addition of A. I + SEB, Cyclo + SEB, SEB, A. I, negative (Neg) control (Cyclo alone) and the unstimulated states in (d) HIV negative (e) viral load < 1000 copies/ mL and (f) viral load > 1000 copies/ mL study groups. Percent levels of CD4+/PD-1+ T cells following stimulation with A. I + SEB, Cyclo + SEB, SEB, A. I, negative (Neg) control (Cyclo alone) and the unstimulated states in (a) HIV negative (b) viral load $<1000 \mathrm{copies} / \mathrm{mL}$ and (c) viral load > 1000 copies/ mL study groups. Statistical evaluation was carried out using the Wilcoxon matched-pairs signed rank test. Each datapoint represents results obtained from individual donor samples

expression by at least 1.4 folds $(p=0.0078)$ and $(\mathrm{p}=$ $0.0156)$ respectively (Fig. $3 \mathrm{~b})$. However, $A$. indica's inhibitory effect on CD69 expression was not replicated in $\mathrm{CD}^{+} \mathrm{T}$ cells from participants with VL greater than 1000 copies $/ \mathrm{mL}(p=0.11)$. Nonetheless, cyclosporine A maintained CD69 inhibition $(p=0.03)$ within this group (Fig. 3c). With regards to $\mathrm{CD}^{+} \mathrm{T}$ cell exhaustion, again $A$. indica extract mirrored cyclosporine A-induced inhibition by lowering Tim-3 ( $p=0.0003)$ and PD-1 ( $p=$ 0.0001 ) in $\mathrm{CD} 4^{+} \mathrm{T}$ cells from HIV negative (Fig. $3 \mathrm{~d}$ and Fig. $3 \mathrm{~g})$ and suppressed VL participants $(\mathrm{p}=0.0078$ for both markers) by 1.7 to 4.2 -fold decrements (Fig. 3e and Fig. 3h). However, both the A. indica extract and cyclosporine A did not reduce SEB-induced Tim-3 and PD-1 in $\mathrm{CD}^{+} \mathrm{T}$ cells from participants with VL greater than 1000 copies/mL (Fig. 3f and i).

\section{Effect of the $A$. indica ethanol-water mixture on gag- specific $C D 4^{+} T$ cell IFN- $\gamma$ and IL-2 response}

Lastly, we turned our efforts towards testing whether A.indica's downmodulation of CD4+ T cell activation/ exhaustion was accompanied by a loss in HIV specific cytokine (IFN- $\gamma$ and IL-2) secretion. This was of interest to us since it has previously been shown that the engagement of $\mathrm{T}$ - cell activation markers such as CD38 influences the secretion of several pro-inflammatory cytokines such as IFN$\gamma$, IL-6, GM-CSF, and IL-10 [46]. Regardless of HIV status and level of viremia, there was no significant difference 
between IFN- $\gamma$ and IL-2 production when comparing the Gag and A. indica + Gag experimental conditions across all study groups (Fig. 4). This implies that $A$. indica extract did not affect $\mathrm{CD}_{4}^{+} \mathrm{T}$ cell IFN- $\gamma$ and IL-2 responses following stimulation with Gag. However, variation in immune deficiency between the viral load $<1000$ copies/ $\mathrm{ml}$ and viral load $>1000$ copies/ ml study groups could account for differences in downmodulation of immune activation seen following testing with $A$. indica (Fig. 5).

\section{Discussion}

Our results support the utility of $A$. indica as a potential source of bioactive compounds for targeting HIV-1 associated immune activation. We exploited commonly used ethnobotanicals that are often alternatively utilized to manage co-infecting diseases like HIV, malaria, tuberculosis and helminths that partially contribute to hyper-immune activation and inflammation in Sub Saharan Africa [47-51]. In Uganda, $A$. indica was amongst the most frequently used herbal therapies utilized for the management of symptoms and opportunistic infections such as cough, fever diarrhoea, abdominal pain, sexually transmitted infections, liver and kidney disease during HIV-1 infection. Based on surveys from questionnaires administered to herbalists, A.indica decoctions prepared from leaves, roots, bulbs and were commonly administered as drinks [7]. Within the plant extract cytotoxicity profiles, the finding that increasing concentration of plant extracts led to progressive loss of cell viability suggests that at high dosages, plant extracts could levy a detrimental toll on cell survival $[52,53]$.
Findings from our study indicate that only the A.indica extract had a potent concentration-dependent inhibitory effect on $\mathrm{CD}^{+} \mathrm{T}$ cell activation and exhaustion following SEB stimulation. Similarly, A. Awah et al also showed that treating PBMCs with phytohemagglutinin (PHA) and a hydroacetone extract of A.indica leaf reduced $\mathrm{CD}_{3} 8^{+}$and $\mathrm{CD} 9^{+}$levels [54]. However, these observations were achieved using PBMCs from only one pooled HIV negative sample which may not account for personal variations in immune activation and functionality [55]. Besides, their findings could have been improved with a comprehensive exploration of $\mathrm{CD} 4+\mathrm{T}$ cell markers of activation and exhaustion like $\mathrm{CD}^{+} 8^{+} \mathrm{HLADR}^{+}$co-expression, Tim3, CD69 and PD-1 which we have done here.

Finally, the immune-suppressive agent Cyclosporine was also noticed to downmodulate $\% \mathrm{CD} 4+\mathrm{CD} 38+$ HLA-DR+ levels following prolonged exposure to SEB. However, the application of Cyclosporine as a future therapeutic agent is limited since it has previously been reported to cause increases in HIV plasma RNA levels [56]. The inhibitory effect of $A$. indica on SEB-induced $\mathrm{CD} 4+\mathrm{T}$ cell activation and exhaustion were dependent on HIV status and viremia of the study participants. A. indica had the most pronounced inhibitory effect on $\mathrm{CD}^{+} \mathrm{T}$ cell activation and exhaustion in PBMCs from HIV-1 negative participants. However, this effect declined but remained significant in participants with suppressed viremia. This was abrogated in participants with non-suppressed viremia with markers CD69 and PD-1 being the most affected.

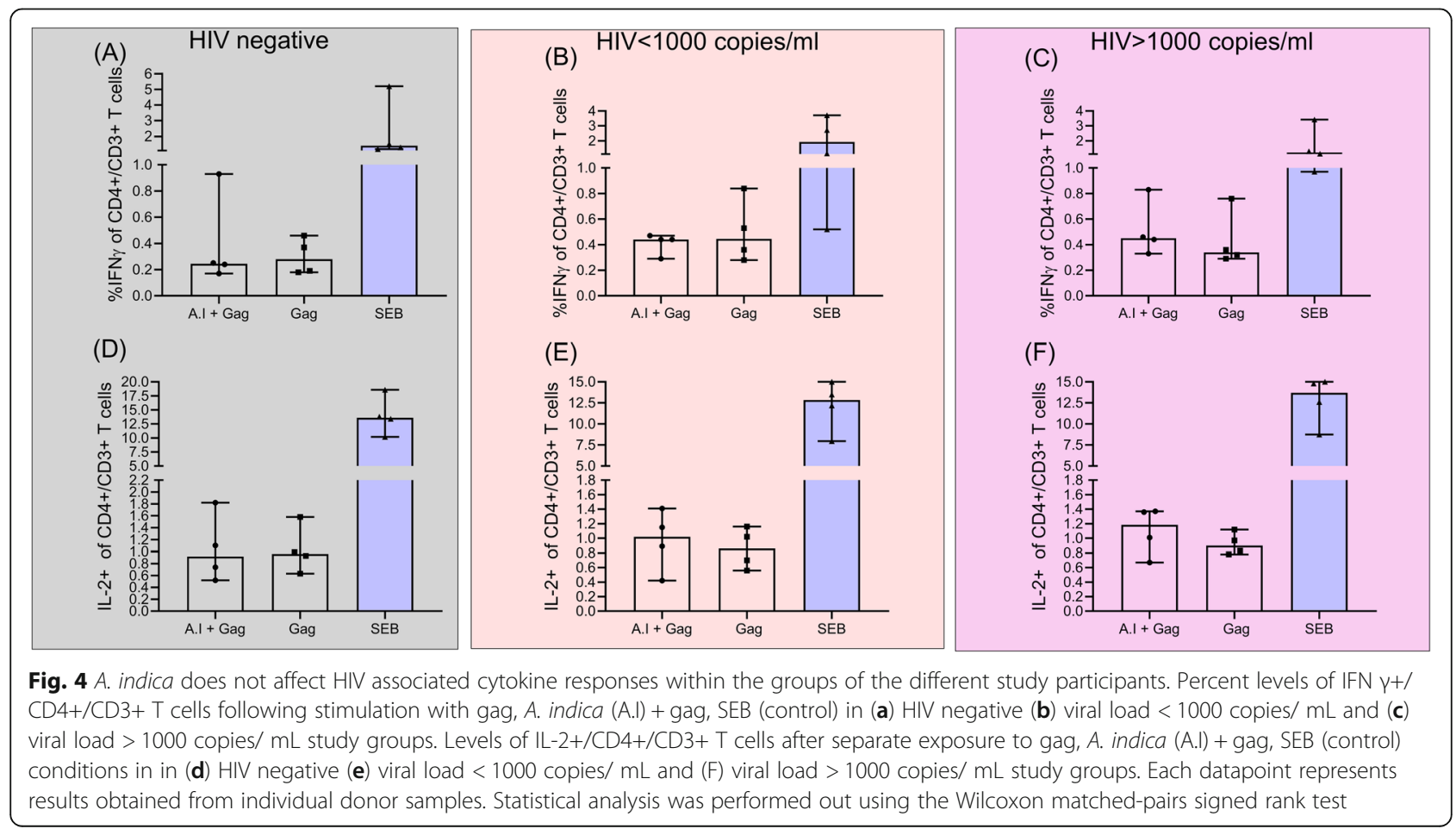




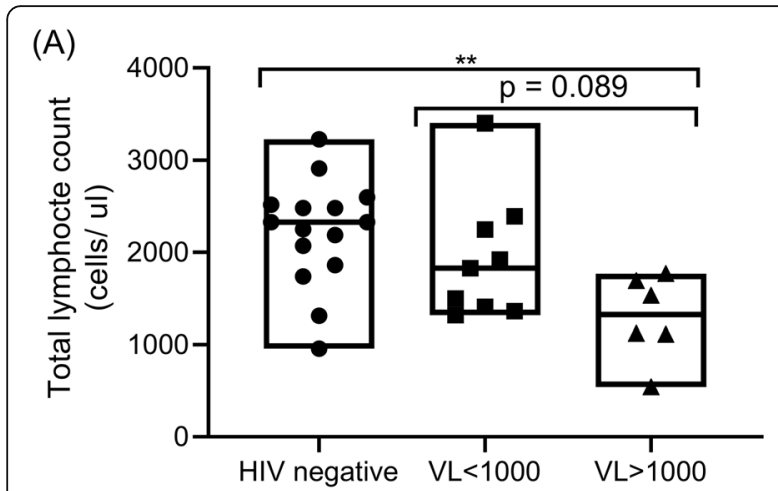

(B)

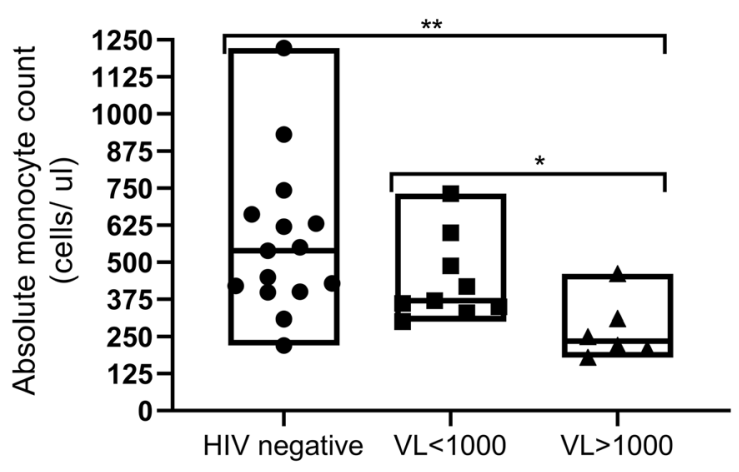

(C)

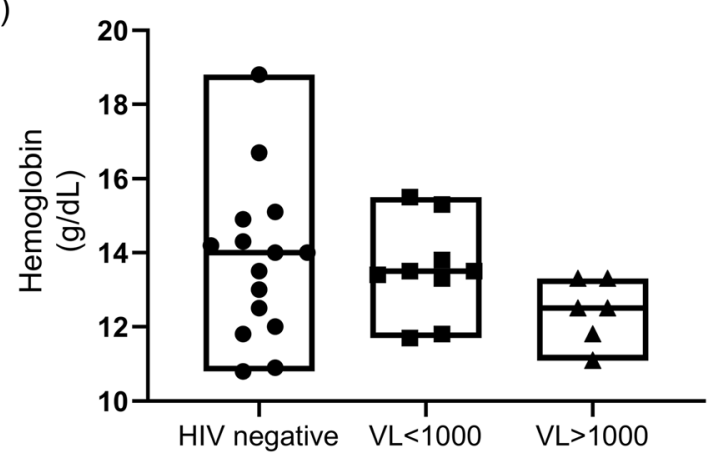

(D)

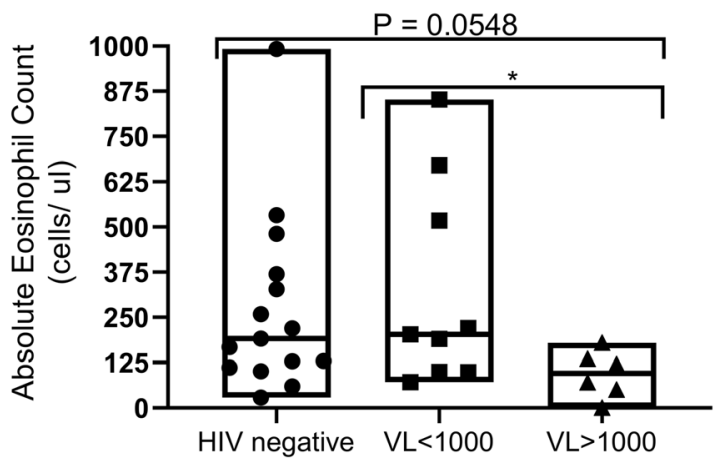

Fig. 5 Differences in key complete blood count profiles among the study groups reveals progressive immune deficiency could account for differences in response to A. indica's down-modulation of CD4+ T cell activation. Absolute counts of (a) Total Lymphocyte (b) monocytes (c) Haemoglobin (d) Eosinophils amongst HIV negative, viral load < 1000 and viral load > 1000 study groups of participants recruited for this study. Each datapoint represents results obtained from individual donor samples

PLWH who have high VL or active viral replication may have low $\mathrm{CD} 4^{+} \mathrm{T}$ cell counts and defective $\mathrm{CD} 4^{+} \mathrm{T}$ cell function as demonstrated by blunted $\mathrm{T}$ cell receptor (TCR) signalling, dysregulation of pro-inflammatory signalling cascades, decreased cytokine secretion and upregulated expression of inhibitory receptors [57, 58]. Thus, non-suppressed HIV infection is associated with systemic immune dysregulation as the immunopathology progresses towards AIDS which may, in part, explain our findings $[59,60]$. While trying to corroborate this ideology, the major limitation that we faced was the fact the standard of patient care was switched to only viral load monitoring as opposed to performing both viral load and CD4+ T cell count testing simultaneously. As a result, we incorporated the use of Total Lymphocyte Count as a substitute for absolute CD4+ $\mathrm{T}$ cell counts for monitoring immune deficiency in HIV infected individuals from resource limited settings [61]. Collectively, the observation of similar total lymphocyte counts and absolute monocyte/ eosinophil counts within the virologically suppressed and healthy groups amidst progressive declines in the $\mathrm{VL}>1000$ individuals confirms the progressive leukocyte depletion and accompanying immune deficiency within the high viral load group.
The observation that ethanolic $A$. indica shows a dosedependent inhibition of CD4+ $\mathrm{T}$ cell activation and exhaustion reveals a novel immune-modulatory role of this plant extract. Similarly, Nakanjako et al found that an $80 \mathrm{mg}$ daily dose of the anti-inflammatory drug Atorvastatin during ART is also capable of reducing T-cell activation/exhaustion within this study population [62]. However, the massive rollout or implementation of statin therapy in concert with ART during HIV infection is limited by drug to drug interactions [63]. Despite several study groups showing that lowering or blockade of checkpoint inhibitors like PD-1 results in the rescue of $\mathrm{T}$ cell function, we did not observe any differences in cytokine specific responses to Gag in A. indica treated versus untreated conditions $[64,65]$.

It could be argued that $A$. indica's reduction of CD4+ $\mathrm{T}$ cell activation/ exhaustion could be due to the result of selective depletion of activated CD4+ T cells. However, our results indicate that the selected concentration of this plant extract was capable of maintaining acceptable cell viabilities during the durations when we conducted our experiments. Thus, to accurately test whether the plant extracts will have any effects on CD4+ cell death on a grandiose scale, markers for apoptosis in 
addition to viability markers and cell death pathways will have to be included in future flow cytometry experiments [66, 67].

Collectively, these findings suggest that the ethanolic extract of $A$. indica is capable of limiting chronic $C D 4^{+}$ $\mathrm{T}$ cell activation and exhaustion without having any effects on the HIV specific cytokine response. Like Chloroquine that has also been reported to have the ability to reduce the levels of CD $4+$ CD38 + HLA-DR+ cells, these substances could be used as adjunct therapies to resolve low-level immune activation and inflammation that persists even after suppressive ART [68, 69]. It should be noted that ethanolic extracts of $A$. indica contain diverse phytochemical constituents ranging from flavonoids, tannins, saponin, steroids and alkaloids [70]. However, future research is required to identify the lead biomolecules contained in this plant extract that could be attenuating $\mathrm{CD} 4^{+} \mathrm{T}$ cell activation/ exhaustion and potential mechanisms of action.

Lastly, we acknowledge that our results could have some weaknesses. The small sample size used limits the power of our study findings. It should also be noted that we and others have used the in-vitro prolonged exposure of PBMCs to SEB to model the continuous exposure of $\mathrm{T}$ cells to bacterial products that goes on during HIV microbial translocation [23]. However, one requires an in-vivo model system like humanized mice or SIV infected non-human primates to accurately study and target the interdependence between chronic immune activation, microbial translocation and increasing antigen burden [71, 72]. Also, there was a high variability observed during SEB induced activation probably due to the elevated exposures to Cytomegalovirus (CMV) within this population. In separate studies, CMV infection has been reported to elevate SEB stimulated immune responses $[73,74]$.

\section{Conclusion}

In summary, this study revealed that $A$. indica contains unknown phytochemicals that are capable of downmodulating chronic HIV associated $\mathrm{CD} 4^{+} \mathrm{T}$ cell activation/ exhaustion. Additional biomolecule identification before testing in other experimental model systems will be required to confirm the possible therapeutic utility of these lead compounds.

\footnotetext{
Abbreviations

A. indica: Azadirachta indicia A. Juss; M. foetida: Momordica foetida Schumach; M.oleifera: Moringa oleifera; Cyclo: Cyclosporine A; SEB: Staphylococcal Enterotoxin B; PD-1: Programmed cell death protein 1; Tim 3: T-cell immunoglobulin and mucin domain-containing protein 3; IFN- $\gamma$ : Interferon gamma; IL-2: Interleukin 2; TNF-a: Tumour necrosis factor alpha; FMO: Fluorescence minus one; PLWH: Persons living with HIV; VL: Viral load; CBC: Complete blood counts; ART: Antiretroviral therapy;

PFA: Paraformaldehyde; HLA-DR: Human Leukocyte Antigen-DR
}

\section{Supplementary Information}

The online version contains supplementary material available at https://doi. org/10.1186/s12906-021-03288-0.

Additional file 1: Supplementary Figure 1. Gating strategy used to delineate the levels of CD4+ T cell immune activation (\%CD4 + CD38 + HLA-DR+ and CD4+ CD69+ T cells) and exhaustion (CD4+ Tim3+/ CD3+ $T$ cells and CD4+ PD-1+/ CD3+ T cells) following stimulation under various conditions. Briefly, single cells were obtained from FSC-H vs FSC-A plots. Then live cells were obtained from exclusion of Amcyan live/ dead dye positive events. Lymphocytes were then excluded from FSCA versus SSC A plots and later CD4+ T cells excluded from CD4+ versus CD3+ plots. CD4 + CD38 + HLA-DR+ levels were then obtained from CD38 versus HLA-DR plots whilst CD4+/CD69+ cells were derived from CD69 vs HLA-DR plots. Lastly, PD-1+ and Tim 3+ CD4+ T cells were also obtained from PD-1/ Tim versus HLA-DR plots respectively

Additional file 2: Supplementary Figure 2. Gating strategy used to explore changes in cytokine (IFNa and IL-2) secretion. Briefly, single cells were excluded using FSCA- FSCH, then live cells obtained from gating out Amcyan positive events. Lymphocytes were then excluded from the FSC-A versus SSC-A plots and T cells further interrogated for CD4+ and CD8+ expression. Levels of IL-2 and IFN $\gamma$ cells were then evaluated under FMO, A. indica + Gag, Gag and SEB conditions respectively

Additional file 3: Supplementary document. Questionnaire that was administered to consenting study participants who were enrolled within the study so as to capture history of previous and current herbal medicine use. In addition, details on alcohol and smoking habits were also obtained.

\section{Acknowledgements}

OAO acknowledges grant support from GSK Trust in Africa. We highly appreciate all study participants for their willingness to participate in this study. Many thanks to Michael A. Eller and Julie Ake who not only pioneered and supported various T cell activation studies within our laboratories but also provided useful suggestions and constructive guidance during the design and formulation of this study.

\section{Authors' contributions}

OAO conceptualized this study and oversaw all study activities. AT and HK ensured this study was carried out under strict ethical and regulatory compliance. GUA carried out sample identification, collection, processing and cataloguing of plant extracts. OAO, BA, PN, JN, MN and FC were involved in performing the cytotoxicity and flow cytometry experiments. OAO, BA, MS, FK and HK oversaw sample collection from the field and performance of field tests like CBC, CD4 counts, HIV screening and viral load testing. FC, BB, AP, SNP provided supervision and mentorship during the course of the study. All authors were involved in the writing and reviewing of this manuscript. The authors read and approved the final manuscript.

\section{Authors' information}

Omalla A Olwenyi is a Doctorate Student / Research Assistant in the Interdisciplinary Graduate Program in Biomedical Sciences (IGPBS) program at the University of Nebraska Medical Center (UNMC). During his PhD in the Byrareddy and Fletcher laboratories, Omalla is training in immunology, virology, and basic bioinformatics.

Bannet Asingura is a Research Associate at the Makerere University Walter Reed Project and lecturing assistant at the Makerere University School of Biomedical Sciences, Department of Immunology and Molecular Biology. Bannet holds a BA in biochemistry and an MSC. in immunology and clinical microbiology.

Prossy Naluyima is the Laboratory Director of Makerere University Walter Reed Project's College of American Pathologists (CAP) accredited Laboratories, overseeing both clinical and research activities. She holds a BSC In Biomedical Laboratory Technology, an MSc in Biomedical Sciences and a $\mathrm{PhD}$ in Medical Sciences specializing in Immunology. Godwin Anywar Upoki: Anywar Godwin has just completed his PhD at Makerere University in Kampala Uganda, the Fraunhofer Institute for Cell Therapy \& Immunology and the Institute for Virology, University of Leipzig, Germany, where he has been investigating the ethnopharmacology, 
cytotoxicity, anti-HIV-1 \& immunomodulatory properties of medicinal plants used by herbalists to treat people living with HIV/AIDS in Uganda. Dr. Hannah Kibuuka is the Executive Director of the Makerere University Walter Reed Project and has served as a lead scientist in several clinical trials carried out in Uganda.

\section{Funding}

This research was supported by the GlaxoSmithKline (GSK) Trust in Africa research grant offered to OAO. In addition, OAO receives on-going support from the Fulbright Foreign Student Program. Both BA and PN received Global Health Travel Awards to present portions of these results at the joint meeting of HIV Vaccines and Functional Cures/ Eradication of HIV held at Fairmont Chateau Whistler, BC Canada on March 24-28, 2019. "The funders had no role in study design, data collection and analysis, decision to publish, or preparation of the manuscript."

\section{Availability of data and materials}

Data and materials are available from authors upon request.

\section{Declarations}

\section{Ethics approval and consent to participate}

All study activities were approved by the Makerere University School of Biomedical Sciences Higher Degrees Research and Ethics Committee, Makerere University School of Public Health Institutional Review Board (Protocol number: 298) and the Uganda National Science of Technology (UNCST number: HS1926). All recruited study participants provided informed consent prior to participation in this study.

\section{Consent for publication}

The possibility of publication of results was discussed with all study participants prior to consensual enrolment. All participants made an informed decision to participate in this study or any study activities related.

\section{Competing interests}

The authors declare that they have no known competing financial interests or personal relationships that could have appeared to influence the work reported in this paper.

\section{Author details}

'Makerere University, Walter Reed Project, P.O Box 16524, Kampala, Uganda. ${ }^{2}$ Department of Pathology and Microbiology, University of Nebraska Medical Center, Omaha, NE, USA. ${ }^{3}$ Department of Pharmacology and Experimental Neuroscience, University of Nebraska Medical Center, Omaha, NE, USA. ${ }^{4}$ Department of Immunology and Molecular Biology, College of Health Sciences, Makerere University, Kampala, Uganda. ${ }^{5}$ Department of Plant Sciences, Microbiology \& Biotechnology, College of Natural Sciences, Makerere University, Kampala, Uganda. ${ }^{6}$ Department of Biochemistry and Molecular Biology, College of Medicine, University of Nebraska Medical Center, Omaha, NE, USA. ${ }^{7}$ Antiviral Pharmacology Laboratory, University of Nebraska Medical Center (UNMC) Center for Drug Discovery, Omaha, NE, USA.

\section{Received: 20 June 2020 Accepted: 25 March 2021}

\section{Published online: 09 April 2021}

\section{References}

1. Van Malderen C, Amouzou A, Barros AJD, Masquelier B, Van Oyen H, Speybroeck N. Socioeconomic factors contributing to under-five mortality in sub-Saharan Africa: a decomposition analysis. BMC Public Health. 2019;19(1): 760.

2. Forsythe SS, McGreevey W, Whiteside A, Shah M, Cohen J, Hecht R, et al Twenty years of antiretroviral therapy for people living with HIV: global costs, health achievements, economic benefits. Health Aff. 2019;38(7):116372. https://doi.org/10.1377/hlthaff.2018.05391.

3. Rosen S, Fox MP. Retention in HIV care between testing and treatment in sub-Saharan Africa: a systematic review. PLoS Med. 2011;8(7):e1001056. https://doi.org/10.1371/journal.pmed.1001056.

4. Petzer $K$, Mngqundaniso N. Patients consulting traditional health practioners in the context of HIV/AIDS in urban areas in KwaZulu-Natal, South Africa. Afr
J Tradit Complement Altern Med. 2008;5(4):370-9. https://doi.org/10.4314/a jtcam.v5i4.31292.

5. Nlooto M, Naidoo P. Traditional, complementary and alternative medicine use by HIV patients a decade after public sector antiretroviral therapy roll out in South Africa: a cross sectional study. BMC Complement Altern Med. 2016;16(1):128. https://doi.org/10.1186/s12906-016-1101-5.

6. Lubinga S, Kintu A, Atuhaire J, Asiimwe S. Concomitant herbal medicine and antiretroviral therapy (ART) use among HIV patients in Western Uganda: a cross-sectional analysis of magnitude and patterns of use, associated factors and impact on ART adherence. AIDS Care. 2012;24(11):1375-83. https://doi.org/10.1080/09540121.2011.648600.

7. Anywar G, Kakudidi E, Byamukama R, Mukonzo J, Schubert A, Oryem-Origa $H$. Indigenous traditional knowledge of medicinal plants used by herbalists in treating opportunistic infections among people living with HIV/AIDS in Uganda. J Ethnopharmacol. 2020;246:112205. PubMed PMID: 31476442. Epub 2019/09/03. eng. https://doi.org/10.1016/j.jep.2019.112205.

8. Namuddu B, Kalyango JN, Karamagi C, Mudiope P, Sumba S, Kalende H, et al. Prevalence and factors associated with traditional herbal medicine use among patients on highly active antiretroviral therapy in Uganda. BMC Public Health. 2011;11(1):855

9. Agosto LM, Henderson AJ. CD4(+) T Cell Subsets and Pathways to HIV Latency. AIDS Res Human Retroviruses. 2018;34(9):780-9 PubMed PMID: 29869531. PMCID: PMC6152855. Epub 2018/06/06. eng.

10. Gonzalez SM, Taborda NA, Rugeles MT. Role of Different Subpopulations of CD8+ T Cells during HIV Exposure and Infection. Front Immunol. 2017; 8(936) English.

11. Bastidas S, Graw F, Smith MZ, Kuster H, Günthard HF, Oxenius A. CD8+ T cells are activated in an antigen-independent manner in HIV-infected individuals. J Immunol. 2014;192(4):1732-44. https://doi.org/10.4049/ jimmunol.1302027.

12. Zevin AS, McKinnon L, Burgener A, Klatt NR. Microbial translocation and microbiome dsybiosis in HIV-associated immune activation. Curr Opin HIV AIDS. 2016;11(2):182-90. https://doi.org/10.1097/COH.0000000000000234.

13. Brenchley JM, Douek DC. Microbial translocation across the Gl tract. Annu Rev Immunol. 2012;30(1):149-73. 22224779. https://doi.org/10.1146/annurevimmunol-020711-075001.

14. Paiardini M, Müller-Trutwin M. HIV-associated chronic immune activation. Immunol Rev. 2013;254(1):78-101 PubMed PMID: 23772616. eng.

15. Hoffmann M, Pantazis N, Martin GE, Hickling S, Hurst J, Meyerowitz J, et al. Exhaustion of activated CD8 T cells predicts disease progression in primary HIV-1 infection. PLoS Pathog. 2016;12(7):e1005661. https://doi.org/10.1371/ journal.ppat.1005661.

16. Velu V, Shetty RD, Larsson M, Shankar EM. Role of PD-1 co-inhibitory pathway in HIV infection and potential therapeutic options. Retrovirology. 2015;12(1):14. https://doi.org/10.1186/s12977-015-0144-X.

17. Trautmann L, Janbazian L, Chomont N, Said EA, Gimmig S, Bessette B, et al. Upregulation of PD-1 expression on HIV-specific CD8+ T cells leads to reversible immune dysfunction. Nat Med. 2006;12(10):1198-202.

18. Dyavar Shetty R, Velu V, Titanji K, Bosinger SE, Freeman GJ, Silvestri G, et al. PD-1 blockade during chronic SIV infection reduces hyperimmune activation and microbial translocation in rhesus macaques. J Clin Invest. 2012;122(5):1712-6.

19. Mylvaganam GH, Chea LS, Tharp GK, Hicks S, Velu V, lyer SS, et al. Combination anti-PD-1 and antiretroviral therapy provides therapeutic benefit against SIV. JCI Insight. 2018;3(18).

20. Boyer Z, Palmer S. Targeting Immune Checkpoint Molecules to Eliminate Latent HIV. Front Immunol. 2018;9(2339) English.

21. Rizzardini G, Trabattoni D, Saresella M, Piconi S, Lukwiya M, Declich S, et al. Immune activation in HIV-infected African individuals. Aids. 1998;12(18): 2387-96. https://doi.org/10.1097/00002030-199818000-00007.

22. Olwenyi OA, Naluyima P, Cham F, Quinn TC, Serwadda D, Sewankambo NK, et al. Brief Report: Differential Associations of Interleukin 6 and Intestinal Fatty Acid-Binding Protein With Progressive Untreated HIV-1 Infection in Rakai, Uganda. J Acq Immune Defic Syndromes. 2016;72(1):15-20 PubMed PMID: 26630672. PMCID: PMC6310136. Epub 2015/12/03. eng.

23. Bourke CD, Gough EK, Pimundu G, Shonhai A, Berejena C, Terry L, et al. Cotrimoxazole reduces systemic inflammation in HIV infection by altering the gut microbiome and immune activation. Sci Transl Med. 2019;11(486): eaav0537.

24. Anywar G, Kakudidi E, Byamukama R, Mukonzo J, Schubert A, Oryem-Origa $H$. Data on medicinal plants used by herbalists for boosting immunity in 
people living with HIV/AIDS in Uganda. Data Brief. 2020;29:105097 PubMed PMID: 31970279. eng.

25. Anywar G, Kakudidi E, Byamukama R, Mukonzo J, Schubert A, Oryem-Origa H. Data on medicinal plants used by herbalists for boosting immunity in people living with HIV/AIDS in Uganda. Data in Brief. 2020;29:105097.

26. Katende A, Birnie A, Tengnas B. Useful trees and shrubs for Uganda. Identification, Propagation and Management for Agricultural and Pastoral Communities Regional Soil Conservation Unit (RSCU), Swedish International Development Authority (SIDA); 1995.

27. Upton R, Graff A, Jolliffe G, Länger R, Williamson E. American herbal pharmacopoeia: botanical pharmacognosy-microscopic characterization of botanical medicines: CRC Press; 2016. https://doi.org/10.1201/b10413.

28. Martin GJ. Ethnobotany: a methods manual (people and plants conservation series): Earthscan Publications; 2010. https://doi.org/10.4324/ 9781849775854

29. Organization WH, Zdrowia ŚO. WHO guidelines on good agricultural and collection practices [GACP] for medicinal plants: World Health Organization; 2003.

30. Inc. ANA. Determine ${ }^{\mathrm{TM}} \mathrm{HIV}-1 / 2 \mathrm{Ag} / \mathrm{Ab}$ Combo. 2013.

31. CHEMBIO DIAGNOSTIC SYSTEMS I. HIV $1 / 2$ STAT-PAK ${ }^{T M}$ assay 2006

32. PLC TB. Uni-Gold ${ }^{T M}$ Recombigen ${ }^{\oplus}$ HIV-1/2; 2012.

33. Sizmann D, Glaubitz J, Simon CO, Goedel S, Buergisser P, Drogan D, et al. Improved HIV-1 RNA quantitation by COBAS ${ }^{\star}$ AmpliPrep/COBAS ${ }^{\circledR}$ TaqMan $^{\bullet}$ HIV-1 test, v2. 0 using a novel dual-target approach. J Clin Virol. 2010;49(1): 41-6. https://doi.org/10.1016/j.jcv.2010.06.004.

34. Sparrow RL, Greening DW, Simpson RJ. A protocol for the preparation of cryoprecipitate and cryodepleted plasma. In: Serum/Plasma Proteomics: Springer; 2011. p. 259-65.

35. Olemukan RE, Eller LA, Ouma BJ, Etonu B, Erima S, Naluyima P, et al. Quality monitoring of HIV-1-infected and uninfected peripheral blood mononuclear cell samples in a resource-limited setting. Clin Vaccine Immunol. 2010;17(6): 910-8. https://doi.org/10.1128/CVI.00492-09.

36. Luminex. Guava ${ }^{\bullet}$ ViaCount ${ }^{\text {TM }}$ Reagent: Optimized for ease of use and deeper, faster scientific insights 2020 [cited 2020 3/10/2020]. Available from: https://www.luminexcorp.com/guava-viacount-reagent-240ml/\#overview.

37. Luminex. Guava ${ }^{\circledR}$ ViaCount $^{\text {TM }}$ Reagent 2020 [cited 2020 3/10/2020]. Available from: https://www.luminexcorp.com/guava-viacount-reagent-40ml/ \#overview.

38. Flores $C$, Fouquet $G$, Moura IC, Maciel TT, Hermine O. Lessons to Learn From Low-Dose Cyclosporin-A: A New Approach for Unexpected Clinical Applications. Front Immunol. 2019;10(588) English.

39. Lam S, Cruz CR, Bollard C. Developing Multi-HIV Antigen Specific T Cells as a Component of a Cure Strategy. 2015. Available from: JPT Application Note at www.jpt.com. [cited 2020 12/1/2020].

40. FlowJo X. v10. 0.7 r2 FlowJo. LLC https://www.flowjo.com. 2020. Cited on $3 / 1 / 2020$.

41. Motulsky H. https://www.graphpad.com/guides/prism/8/statistics/ Online2020 [cited 2020 1/12/2020].

42. Ellman TM, Alemayehu B, Abrams EJ, Arpadi S, Howard AA, El-Sadr WM. Selecting a viral load threshold for routine monitoring in resource-limited settings: optimizing individual health and population impact. J Int AIDS Soc. 2017;20(57):e25007.

43. Uganda MoH. CONSOLIDATED GUIDELINES FOR THE PREVENTION AND TREATMENT OF HIV AND AIDS IN UGANDA 2018 [cited 2020 5/10/2020]. Available from: https://elearning.idi.co.ug/pluginfile.php/5675/mod_page/ content/19/Uganda\%20HIV\%20\%20Guidelines\%20-\%20September\%202018. pdf.

44. Lan S-F, Safiejko-Mroczka B, Starly B. Long-term cultivation of HepG2 liver cells encapsulated in alginate hydrogels: A study of cell viability, morphology and drug metabolism. Toxicology in Vitro. 2010;24(4):1314-23.

45. ISO P. 10993-5: 2009 Biological Evaluation of Medical Devices_Part 5: Tests for In Vitro Cytotoxicity. Geneva: International Organization for Standardization; 2009.

46. Ausiello CM, La Sala A, Ramoni C, Urbani F, Funaro A, Malavasi F. Secretion of IFN-Y, IL-6, granulocyte-macrophage colony-stimulating factor and IL-10 cytokines after activation of human purified T lymphocytes upon CD38 ligation. Cell Immunol. 1996;173(2):192-7. https://doi.org/10.1006/cimm.1996.0267.

47. Clerici M, Butto S, Lukwiya M, Saresella M, Declich S, Trabattoni D, et al. Immune activation in Africa is environmentally-driven and is associated with upregulation of CCR5. Aids. 2000;14(14):2083-92. https://doi.org/10.1097/ 00002030-200009290-00003.
48. Lawn SD. AIDS in Africa: the impact of coinfections on the pathogenesis of HIV-1 infection. J Infect. 2004;48(1):1-12.

49. Boulougoura A, Sereti I. HIV infection and immune activation: the role of Coinfections. Curr Opin HIV AIDS. 2016;11(2):191-200. https://doi.org/10.1097/ COH.0000000000000241.

50. Sullivan ZA, Wong EB, Ndung'U T, Kasprowicz VO, Bishai WR. Latent and active tuberculosis infection increase immune activation in individuals coinfected with HIV. EBioMedicine. 2015;2(4):334-40. https://doi.org/10.1016/j. ebiom.2015.03.005.

51. Pastor L, Urrea V, Carrillo J, Parker E, Fuente-Soro L, Jairoce C, et al. Dynamics of CD4 and CD8 T-Cell Subsets and Inflammatory Biomarkers during Early and Chronic HIV Infection in Mozambican Adults. Front Immunol. 2018;8(1925) English.

52. Ala AA, Olotu BB, Ohia CMD. Assessment of cytotoxicity of leaf extracts of Andrographis paniculata and Aspilia africana on murine cells in vitro. Arch Basic Appl Med. 2018;6(1):61-5 PubMed PMID: 30234147. Epub 05/13. eng.

53. Chan SM, Khoo KS, Sit NW. Interactions between plant extracts and cell viability indicators during cytotoxicity testing: implications for ethnopharmacological studies. Trop J Pharm Res. 2015;14(11):1991-8. https://doi.org/10.4314/tjpr.v14i11.6.

54. Awah F, Uzoegwu P, Ifeonu P. In vitro anti-HIV and immunomodulatory potentials of Azadirachta indica (Meliaceae) leaf extract. Afr J Pharm Pharmacol. 2011;5(11):1353-9. https://doi.org/10.5897/AJPP11.173.

55. Brodin P, Davis MM. Human immune system variation. Nat Rev Immunol. 2017;17(1):21-9. https://doi.org/10.1038/nri.2016.125.

56. Calabrese LH, Lederman MM, Spritzler J, Coombs RW, Fox L, Schock B, et al. Placebo-controlled trial of cyclosporin-A in HIV-1 disease: implications for solid organ transplantation. J Acq Immune Defic Syndr. 2002;29(4):356-62.

57. Reuter MA, Pombo C, Betts MR. Cytokine production and dysregulation in HIV pathogenesis: lessons for development of therapeutics and vaccines. Cytokine Growth Factor Rev. 2012;23(4-5):181-91 PubMed PMID: 22743036. Epub 06/27. eng.

58. Hyun J, MCMahon RS, Lang AL, Edwards JS, Badilla AD, Greene ME, et al. HIV and $\mathrm{HCV}$ augments inflammatory responses through increased TREM-1 expression and signaling in Kupffer and myeloid cells. PLoS Pathog. 2019; 15(7):e1007883. https://doi.org/10.1371/journal.ppat.1007883.

59. Zoufaly A, Kiepe J, Hertling S, Hüfner A, Degen O, Feldt T, et al. Immune activation despite suppressive highly active antiretroviral therapy is associated with higher risk of viral blips in HIV-1-infected individuals. HIV medicine. 2014;15(8):449-57. https://doi.org/10.1111/hiv.12134.

60. Khaitan A, Unutmaz D. Revisiting immune exhaustion during HIV infection. Current HIV/AIDS Reports. 2011;8(1):4-11. https://doi.org/10.1007/s11904-01 0-0066-0.

61. Obirikorang C, Quaye L, Acheampong I. Total lymphocyte count as a surrogate marker for CD4 count in resource-limited settings. BMC Infect Dis. 2012;12(1):128.

62. Nakanjako D, Ssinabulya I, Nabatanzi R, Bayigga L, Kiragga A, Joloba M, et al. Atorvastatin reduces T-cell activation and exhaustion among HIV-infected CART-treated suboptimal immune responders in Uganda: a randomised crossover placebo-controlled trial. Trop Med Int Health. 2015;20(3):380-90 PubMed PMID: 25441397. Epub 01/06. eng.

63. Maggi P, De Socio GV, Cicalini S, D'Abbraccio M, Dettorre G, Di Biagio A, et al. Statins and aspirin in the prevention of cardiovascular disease among HIVpositive patients between controversies and unmet needs: review of the literature and suggestions for a friendly use. AIDS Res Ther. 2019;16(1):11.

64. Kamphorst AO, Wieland A, Nasti T, Yang S, Zhang R, Barber DL, et al. Rescue of exhausted CD8 T cells by PD-1-targeted therapies is CD28-dependent. Science. 2017;355(6332):1423-7 PubMed PMID: 28280249. Epub 03/09. eng.

65. Beldi-Ferchiou A, Caillat-Zucman S. Control of NK cell activation by immune checkpoint molecules. Int J Mol Sci. 2017;18(10):2129. https://doi.org/10.33 90/ijms18102129.

66. Wlodkowic D, Skommer J, Darzynkiewicz Z. Flow Cytometry-based apoptosis detection. In: Erhardt P, Toth A, editors. Apoptosis: methods and protocols, Second Edition. Totowa, NJ: Humana Press; 2009. p. 19-32. https://doi.org/10.1007/978-1-60327-017-5_2.

67. Galluzzi L, Vitale I, Aaronson SA, Abrams JM, Adam D, Agostinis P, et al. Molecular mechanisms of cell death: recommendations of the Nomenclature Committee on Cell Death 2018. Cell Death Differ. 2018;25(3):486-541.

68. Murray SM, Down CM, Boulware DR, Stauffer WM, Cavert WP, Schacker TW, et al. Reduction of immune activation with chloroquine therapy during chronic HIV infection. J Virol. 2010;84(22):12082-6. https://doi.org/10.1128/ JVI.01466-10. 
69. Routy JP, Angel J, Patel M, Kanagaratham C, Radzioch D, Kema I, et al. Assessment of chloroquine as a modulator of immune activation to improve CD4 recovery in immune nonresponding HIV-infected patients receiving antiretroviral therapy. HIV Med. 2015;16(1):48-56. https://doi.org/1 0.1111/hiv. 12171 .

70. Susmitha S, Vidyamol K, Ranganayaki P, Vijayaragavan R. Phytochemical extraction and antimicrobial properties of Azadirachta indica (Neem). Global J Pharmacol. 2013;7(3):316-20.

71. Del Prete GQ, Lifson JD. Considerations in the development of nonhuman primate models of combination antiretroviral therapy for studies of AIDS virus suppression, residual virus, and curative strategies. Curr Opin HIV AIDS. 2013;8(4):262-72. https://doi.org/10.1097/COH.0b013e328361cf40.

72. Dash PK, Kaminski R, Bella R, Su H, Mathews S, Ahooyi TM, et al. Sequentia LASER ART and CRISPR treatments eliminate HIV-1 in a subset of infected humanized mice. Nat Commun. 2019:10(1):1-20

73. Pera A, Campos C, Corona A, Sanchez-Correa B, Tarazona R, Larbi A, et al. CMV latent infection improves CD8+ T response to SEB due to expansion of polyfunctional CD57+ cells in young individuals. PloS one. 2014;9(2):e88538 PubMed PMID: 24533103. PMCID: PMC3922920. Epub 2014/02/18. eng.

74. Stockdale L, Nash S, Nalwoga A, Painter H, Asiki G, Fletcher H, et al. Human cytomegalovirus epidemiology and relationship to tuberculosis and cardiovascular disease risk factors in a rural Ugandan cohort. PloS one. 2018; 13(2):e0192086 PubMed PMID: 29408860. PMCID: PMC5800673. Epub 2018/ 02/07. eng.

\section{Publisher's Note}

Springer Nature remains neutral with regard to jurisdictional claims in published maps and institutional affiliations.

Ready to submit your research? Choose BMC and benefit from:

- fast, convenient online submission

- thorough peer review by experienced researchers in your field

- rapid publication on acceptance

- support for research data, including large and complex data types

- gold Open Access which fosters wider collaboration and increased citations

- maximum visibility for your research: over $100 \mathrm{M}$ website views per year

At BMC, research is always in progress.

Learn more biomedcentral.com/submissions 